\title{
KONSEP PENDIDIKAN SEBAGAI SUATU SISTEM DAN KOMPONEN SISTEM PENDIDIKAN
}

\author{
Oleh : Ratih Elvikha Yulasri \\ Administrasi Pendidikan \\ Fakultas Ilmu Pendidikan-UNP \\ Email : elvikharatih@gmail.com
}

\begin{abstract}
ABSTRAK
Artikel ini bertujuan untuk menggambarkan bagaimana sistem pendidikan di Indonesia. Pendidikan merupakan suatu sistem yang terdiri dari beberapa komponen yang saling berkaitan satu sama lain. Banyak orang yang beranggapan bahwa suatu keberhasilan atau kegagalan yang dialami oleh seseorang tergantung kepada apa yang didapatkannya selama di sekolah. Mereka tidak tau bahwa pendidikan tidak hanya persekolahan tapi banyak sekali faktor yang dapat menentukan keberhasilan atau kegagalan dari seseorang salah satunya adalah kerjasama antar faktor-faktor pendidikan itu. Di Indonesia sistem pendidikannya di dasarkan pada sistem pendidikan nasional, namun banyak sekali terdapat kesenjangan antara tujuan dan kenyataannya. Hal ini diakibatkan dari kurangnya kerjasama komponen pendidikan dan kelemahan manajemen serta dukungan dari pemerintah dan masyarakat masih sangat rendah.

Kata Kunci : sistem pendidikan, komponen pendidikan, faktor pendidikan

\section{Pendahuluan}

Pendidikan merupakan suatu sistem, sebagai suatu sistem pendidikan terdiri atas beberapa komponen diantaranya yaitu tujuan, pendidik, peserta didik, materi, metode atau media pembelajaran, serta lingkungan pendidikan. Setiap komponen mempunyai fungsi masingmasing dan setiap komponen saling mempengaruhi satu sama lain. Di era sekarang ini banyak sekali permasalahan yang diakibatkan oleh berbagai macam perubahan seperti perubahan sosial dan budaya serta perubahan teknologi yang menyebabkan berdampak kepada kemajuan dan
\end{abstract}


perkembangan pendidikan. Indonesia sendiri merupakan negara yang sedang berkembang yang sedang berusaha menjadi negara maju terutama maju dalam dunia pendidikan. Sistem pendidikan di Indonesia masih menggunakan atau masih mengacu pada sistem pendidikan nasional

Pada saat sekarang ini dalam penyelenggaran pendidikan masyarakat masih belum menyadari bahwa pendidikan berasal dari suatu sistem, masih banyak masyarakat yang belum menyadari bahwa dirinya merupakasn salah satu komponen yang terlibat dalam keberhasilan dan kegagalan dari suatu pendidikan. Melalui pendidikan ini diharapkan dapat memberikan informasi bagaimana sistem pendidikan di Indonesia pada saat ini dan bisa dijadikan informasi tentang berbagai komponen dalam masalah pendidikan.

\section{Pendidikan Sebagai Suatu Sistem}

Pendidikan adalah usaha untuk memanusiakan manusia, pendidikan bermaksud membantu manusia untuk menumbuhkembangkan potensi-potensi kemanusiaannya. Oleh sebab itu manusia tidak dapat terlepas dari lingkungannya ini lah yang menyebabkan kenapa manusia sangat berkaitan erat dengan lingkungan. Salah satu cara untuk memperoleh gambaran yang lebih mantap tentang pendidikan adalah menggunakan pendekatan sisitem. Tujuan dari pendekatan dsistem dalam pendidikan sendiri ialah untuk memaksimalkan pencapaian tujuan yang telah ditetapkan.

Sistem merupakan suatu totalitas yang terpadu dari semua elemen dan semua kegiatan saling berkaitan satu sama lain secara fungsional agar dapat mencapai tujuan. Maksud dari pendidikan sebagai suatu sistem adalah pendidikan sendiri terdiri dari elemen-elemen atau unsurunsur pendididkan yang dalam kegiatannya saling terkait secara fungsional, sehingga merupakan satu kesatuan yang terpadu dan diharapkan dapay mencapai tujuan.

\section{Komponen Pendidikan}

Dalam kegiatan atau proses pendidikan terdapat komponen pendidikan yang dapat membentuk pola interaksi atau saling mempengaruhi satu sama lain, komponen pendidikan tersebut antara lain :

1. Tujuan 
Tujuan merupakan komponene pendidikan yang merupakan komponen yang sangat penting dalam proses pendidikan itu sendiri. Tujuan pendidikan sangat diinginkan oleh seorang pendidik agar peserta didik dapat mencapainya dengan syarat tujuan tersebut tidak bertentangan hakikat perkembangan peserta didik dan dapat diterima sebagai nilai hidup yang baik. Dalam sisitem pendidikan terdapat empat jenjang tujuan pendidikan yaitu :

a. Tujuan umum pendidikan, yakni manusia pancasila

b. Tujuan institusional (tujuan lembaga pendidikan, misalnya tujuan sekolah dasar, tujuan Universitas)

c. Tujuan kurikuler ( tujuan standar kompetensi atau bidang studi, misalnya tujuan IPA,IPS dan agama)

d. Tujuan instruksional kompetensi dasar (tujuan untuk setiap kegiatan) proses belajar mengajar.

2. Pendidik

Dalam Undang-Undang Nomor 20 tahun 2003 tentang Sistem Pendidikan Nasinal pada Bab XI pasal 39 tentang Pendidik dan Tenaga Kpendidikan dinyatakan bahwa pendidik merupakan tenaga professional yang bertugas merencanakan dan melaksanakan proses pembelajaran, menilai hasil pembelajaran melakukan pembimbingan dan pelatiha, serta melakukan penelitian dan pengabdian kepada masyarakat terutama bagi pendidik di perguruan tinggi.

(Arifin, 2015)Saat mengatakan bahwa pendidik adalah orang yang diberi amanah untuk tidak saja membuat perencanaan, melaksanakan pembelajaran, menilai, membimbing tetapi juga melakukan peneliian dan pengabdian kepada masyarakat. Dari pendapat diatas dapat disimpulkan bahwa pendidik merupakan orang yang mempunyai tanggung jawab dalam melaksanakan pendidikan .

3. Peserta didik

Peserta didik merupakan manusia yang memiliki potensi dan mengalami perkembangan sejak dilahirkan sampai meninggal dunia. Salah satu tugas pendidik adalah mengembangkan potensi yang dimiliki oleh peserta didik, namun sebagai seoranng pendidik harus bisa perkembangan dan potensi-potensi yang dimiliki oleh masing-masing peserta didik karna pada umumnya potensi peserta didik tidaklah sama tapi berbeda-beda. 
4. Media, metode dan alat

Media pendidikan merupakan sesuatu yang digunakan oleh seorang pendidik untuk menjadi perantara dalam proses pembelajaran sedangkan metode merupakan car yang berfungsi sebagai alat untuk mencapai tujuan dan alat pendidikan lebih mengarah kepada apa saja yang digunakan untuk mencapai tujuan seperti benda, media, aturan dan hukuman sehingga tujuan dari pendidikan itu sendiri dapat tercapai.

5. Materi pendidikan

Berdasarkan tujuan yang ingin dicapai sebelumnya guru harus menetapkan materi pendidikan yang akan dipelajari peserta didik dan materi tersebut harus yang relevan. Materi yang diberikan harus sesuai dengan tujuan pendidikan yang mengandung nilainilai sesuai dengan pandangan hidup bangsa

6. Lingkungan

Wasty Soemanto (1984:80) mengemukakan bahwa lingkungan mencakup segala material dan stimuli di dalam dan diluar diri individu baik yang bersifat fisiologis, psikologis maupun sosial kultural. Dalam dunia pendidikan lingkungan sangat berpengaruh dalam keberhasilan atau kegagalan dari pendidikan. Namun masih banyak masyarakat yang belum menyadari bahwa lingkungan juga ikut berperan penting dalam proses pembelajaran sehingga masyarakat hanya mengandalkan guru dalam membimbing peserta didik. Lingkungan yang sangat berpengaruh sekali dalam mengembangkan potensi dari seorang peserta didik adalah lingkungan keluarga, karena keluarga merupakan madrasah pertama yang akan diterima oleh seorang anak. selain keluarga lingkunga sekolah juga berpengaruh dalam mengembangkan potensi seseorang. Tidak hanya itu lingkungan masyarakat juga dapat mempengarujhi perilaku dan kemampuan dari seorang peserta didik. Jika peserta didik lahir di lingkungan yang tidak baik maka kemungkinan besar peserta dididk tersebut akan terpengaruh menjadi tidak baik pula namun sebaliknya jika lingkungannya baik maka peserta didik dapat menjadi baik pula.

\section{Gambaran Umum Sistem Pendidikan di Indonesia}

Sistem pendidikan di Indonesia masih menganut Sistem Pendidikan Nasional secara keseluruhan dapat dilihat dari berbagai aspek seperti :

\section{Pengelolaan}


Sistem pendidikan dikelola secara sentralistik dan berlaku untuk seluruh wilayah Indonesia, yang mana semua komponen pendidikan dan proses pendidikannya diatur oleh pemerintah pusat dan berlaku untuk semua sekolah di ndonesia termasuk sekolah yang di pelosok tanah air. Disamping itu ada juga sistem pendidikan yang dikelola oleh masyarakat seperti sekolah swasta.

Menurut (Munirah, 2015)sistem pendidikan berorientasi kepada kepentingan dan bukan untuk kepentingan anak didik, pasar dan pengguna jasa pendidikan atau masyarakat dengan dalih, bahwa strategi pendidikan nasional adalah untuk membekali generasi muda agar mampu membawa bangsa dan negeri ini cepat sejajar dengan bangsa dan negara lain yang lebih maju. Namun pada kenyataannya hasilnya tidak diperoleh tidak sesuai dengan apa yang di cita-citakan, keahlian dan penguasaan IPTEK yang diperoleh setelah lulus dari sekolah hanya digunakan untuk semata-mata mencari uang bukan untuk menjadikan diri sebagai ilmuan yang peduli dengan nilai kemanusiaan, bangsa dan negara.

2. Peran pemerintah dan masyarakat

Pemerintah merupakan pihak yang mengendalikan dan mengelola sistem pendidikan secara nasional walaupun pada hakikatnya dalam undang-undang masyarakatlah yang memiliki kesempatan yang luas untuk menyelenggarakan pendidikan agar mencapai tujuan namun pada akhirnya pemerintah yang menyelenggarakannya. Pemerintah bertugas untuk melakukan pengawasan terhadap penyelenggaraan pendidikan baik itu yang diselenggarakan pemerintah maupun masyarakat sendiri.

3. Dana

Dana merupakan salah satu syarat yang dapat menentukan keberhasilan atau kegagalan dari suatu pendidikan. Dalam penyelenggaraan pendidikan dana sangat dibutuhkan demi kemajuan suatu pendidikan. Masalah yang sering dihadapi oleh pendidikan nasional dalam memperoleh dan menggunakan anggaran pendidikan adalah banyaknya instansi atau departemen pemerintah yang terlibat lengkap dengan kewenangannya masingmasing.

4. Materi

Orientasi penyusunan materi diarahkan untuk memenuhi kepentingan pemerintah agar target pembangunan dapat mengejar pertumbuhan yang telah ditetapkan. Padahal sebenarnya dalam globalisasi menuntut agar materi ajar diorientasikan demi kepentingan 
anak didikdan sesuai pembangunan IPTEK. Kurikulum yang diberikan sering berubahubah dan tidak konsisten sehingga peserta didik dan pendidik susah untuk menyesuaikan diri.

\section{Kesimpulan}

Pendidikan sebagai sistem adalah pendidikan sendiri terdiri dari elemen-elemen atau unsur-unsur pendididkan yang dalam kegiatannya saling terkait secara fungsional, sehingga merupakan satu kesatuan yang terpadu dan diharapkan dapat mencapai tujuan.dalam proses atau kegiatan pendidikan terdapat beberapa komponen yang harus dimiliki seperti tujuan pendidikan, pendidik, peserta didik, metode, media dan alat pendidikan, materi pendidikan, serta lingkungan yang sangat mempengaruhi keberhasilan dari suatu pendidikan.

Pada saat sekarang ini sistem pendidikan di Indonesia masih menganut sistem pendidikan nasional yang mana pemerintah lebih memliki peran yang paling banyak dalam menjalankan sistem pendidikan. Sistem pendidikan dikelola secara sentralistik dan berlaku untuk seluruh wilayah Indonesia, yang mana semua komponen pendidikan dan proses pendidikannya diatur oleh pemerintah pusat dan berlaku untuk semua sekolah di ndonesia termasuk sekolah yang di pelosok tanah air

\section{DAFTAR PUSTAKA}

Arifin, H. M. (2015). Faktor-faktor determinan dalam pendidikan. 8(2), 1-17.

Munirah. (2015). Sistem Pendidikan Di Indonesia: antara keinginan dan realita. AULADUNA, 2, $233-245$.

Syafril \& Zelhendri Zen. 2017. Dasar-Dasar Ilmu Pendidikan. Jakarta: Kencana. 
